Research Article

\title{
The Psychopathology Changes in non-Obese PCOS Women Do Not Show any Influence on Neuropeptide $Y$ Level
}

\author{
Perubahan Psikopatologi pada Pasien PCOS nir Obese \\ tidak Berpengaruh pada Kadar Neuroeptide $Y$ \\ Mariza Yustina $^{1}$, Andon Hestiantoro', Sylvia D. Elvira ${ }^{\mathbf{2}}$ \\ ${ }^{1}$ Department of Obstetrics and Gynecology \\ ${ }^{2}$ Department of Phsychiatry \\ Faculty of Medicine University of Indonesia/ \\ Dr. Cipto Mangunkusumo Hospital \\ Jakarta
}

\begin{abstract}
Objective: To compare the Neuropeptide Y (NPY) levels in nonobese Polycystic Ovary Syndrome (PCOS) patients without insulin resistance and non-obese women without insulin resistance, in consideration of the psychopathologic conditions occurring in PCOS patients as well as the influence of these changes in affecting NPY levels.

Methods: The subject was fourteen PCOS patients and 20 non-obese normal women, both without insulin resistance. The measurements of blood NPY levels using the ELISA method and a psychology assessment using Symptom Check List 90 (SCL-90) were carried out. Statistical analysis was performed using SPSS 17.

Results: From 20 PCOS patients included in this study, 6 subjects (30\%) were detected as having psychopathologic problems through completion of the SCL-90 questionnaire, with a cut-off score of $>70$ points. Measurement of NPY levels using ELISA found a mean NPY level of $8.02 \pm 3.92$ (95\% CI 2.39 - 18.66) in the PCOS group compared to a mean of $7.78 \pm 4.31 \mathrm{pg} / \mathrm{ml}(95 \%$ CI $0.74-15.47)$ in the control group. No significant difference was found in the mean levels of NPY between the two groups. Statistical assessment using the Spearman 2-variable correlation test also found no significant correlation between NPY levels and the SCL-90, scores in the PCOS group.

Conclusion: There was no significant difference in NPY levels between the PCOS group and control group. Thirty percent of non-obese PCOS patients without insulin resistance were identified as having psychopathologic conditions. But in this group of patients, the psychopathologic changes had no influence on the levels of blood NPY. [Indones J Obstet Gynecol 2012; 36-3: 125-9]
\end{abstract}

Keywords: neuropeptide Y, PCOS, psychopathologic conditions

\begin{abstract}
Abstrak
Tujuan: Membandingkan kadar NPY pada pasien Sindroma Ovarium Poli Kistik (SOPK) nir-obese tanpa resistensi insulin dengan perempuan nir-obese tanpa resistensi insulin, dan mengetahui adanya kondisi psikopatologis yang terjadi pada penderita SOPK nir-obese tanpa resistensi insulin, serta mengetahui pengaruhnya terhadap kadar NPY.

Metode: Dilakukan pemeriksaan kadar neuropeptida Y dalam darah dengan metode ELISA dan penilaian kondisi psikologis dengan menggunakan Symptom Check List 90 (SCL-90) pada empat belas sampel penderita SOPK dan 20 perempuan normal nir-obese dan tanpa resistensi insulin. Analisis statistik dilakukan dengan SPSS 17.

Hasil: Di antara 20 subjek penderita sindroma ovarium polikistik didapatkan 6 subjek (30\%) mengalami gangguan psikopatologi yang terdeteksi melalui hasil pengisian kuesioner SCL 90 di mana pada kelompok tersebut didapatkan hasil kuesioner $>70$. Dari pengukuran kadar NPY dengan metode ELISA didapatkan rerata kadar NPY pada kelompok penderita SOPK nir-obese dan tanpa resistensi insulin adalah 8,02 pg/ml $\pm 3,92$ (IK 95\%; 2,39-18,66) dan 7,78 pg/ml $\pm 4,31$ (IK 95\%; 0,74-15,47) pada perempuan normal nir-obese tanpa resistensi insulin. Tidak terdapat perbedaan bermakna pada rerata nilai $N P Y$ pada kedua grup dengan nilai $p>0,05$. Dengan uji statistik korelasi 2 variabel Spearman tidak didapatkan hubungan antara kadar NPY dengan nilai SCL pada kelompok penderita SOPK, dengan nilai $p>0,05$.

Kesimpulan: Tidak terdapat perbedaan kadar NPY yang bermakna antara kelompok SOPK nir-obese tanpa resistensi insulin dan perempuan normal nir-obese. Sekitar 30\% penderita SOPK nir-obese tanpa resistensi insulin mengalami kondisi psikopatologis dan kondisi psikopatologis tidak berpengaruh terhadap kadar NPY pada penderita SOPK nir-obese tanpa resistensi insulin.

[Maj Obstet Ginekol Indones 2012; 36-3: 125-9]
\end{abstract}

Kata kunci: kondisi psikopatologis, neuropeptida Y, SOPK

Correspondence: Mariza Yustina, Department of Obstetrics and Gynecology, Faculty of Medicine University of Indonesia, Jakarta Pusat. Telephone: 082114516067, Email: dr_marizayustina@yahoo.com

\section{INTRODUCTION}

Polycystic Ovary Syndrome (PCOS) is the most common endocrine disorder in women, occurring in $5-7 \%$ of women in reproductive age. ${ }^{1}$ PCOS patients experience various clinical symptoms including oligo- or amenorrhea with infertility, a hyper- androgenism condition manifested as hirsutism, acne, androgenic alopecia, as well as systemic disorders such as obesity, dyslipidemia, insulin resistance and hyperinsulinism. ${ }^{2}$ The presence of these systemic disorders places patients at a high risk for diabetes mellitus and cardiovascular disorders. ${ }^{3}$ 
In PCOS, a neuroendocrine disturbance occurs in the form of increased gonadotropin releasing hormone (GnRH) pulsatility, leading to a dominance of luteinizing hormone (LH) secretion over follicle stimulating hormone (FSH) secretion that causes an elevation in the LH:FSH ratio. ${ }^{2}$ This increased LH stimulation on the theca cells leads to the occurrence of hyperandrogenism, further intensified by insulin resistance. ${ }^{4}$

$\mathrm{GnRH}$ is secreted in a pulsatile fashion. Episodic secretion of GnRH indicates the presence of intrinsic neuronal activity from the hypothalamus. Various neurotransmitters influence GnRH secretion, including GnRH itself, prolactin, norepinephrine, galanin, $\beta$-endorphin, dopamine, and neuropeptide Y. ${ }^{5}$ Other factors influencing secretion of GnRH includes angiotensin II, serotonin, neurotensin, somatostatin, corticotrophin releasing factor (CRF), melantonin, oxytocin, and substance P. ${ }^{4}$

Neuropeptide Y (NPY) increases secretion of GnRH through central action on the terminal axon of $\mathrm{GnRH}$ in the mediobasal of hypothalamus and increases the number of GnRH receptors in the gonadotrophic hypophysis. ${ }^{6} \mathrm{NPY}$ is also an orexigenic peptide that along with galanin, modulates the appetite and holds an important role in the mechanism of GnRH secretion.?

Barnowska et al found an elevation of NPY levels in both obese and non-obese PCOS patients, although the extent of elevation is not correlated to the increase of body mass index (BMI). ${ }^{7}$ Meanwhile, Generelli et al reported similar NPY levels between PCOS patients and normal ovulating women. They also observed a disturbance in counterregulatory responses towards hypoglycemia in relation to NPY secretions in obese PCOS patients. ${ }^{8}$ Levels of NPY are influenced by the presence of insulin resistance, leptin resistance, psychopathologic conditions, cannabinoid substances, and ghrelin. Several studies have observed the psychopathologic problems occurring in PCOS. ${ }^{9,10}$ Literatures show that these psychopathologic problems influence NPY secretion, and thus indirectly affecting the GnRH secretion. There is a different physiologic response towards acute and chronic psychopathologic conditions, while the psychopathology in PCOS is generally chronic. The presence of psychopathology could affect the quality of life and the success of PCOS therapy.

Clomiphene citrate is commonly used for induction of ovulation in PCOS patients, while insulin re- sistance is managed by administration of metformin. In a study carried out by Imani et al, it was found that $30 \%$ of PCOS patients did not show a good response towards clomiphene citrate administration. ${ }^{11}$ Failure mainly occured in the non-obese PCOS patient that did not have insulin resistance. Therefore, more thorough research is needed regarding central factors in the pathophysiology of PCOS that help increase success of therapy. Considering the various factors that could increase the pulsatility of $\mathrm{GnRH}$, including psychopathologic conditions in PCOS patients, this study aims to determine NPY levels in non-obese PCOS patients without insulin resistance, as well as focusing on psychopathologic condition of patients that could potentially influence the pathophysiology of PCOS.

\section{METHODS}

The research was conducted in Department of Obstetrics and Gynecology FKUI-RSCM from October 2011 to December 2011. We recruited 20 patients with PCOS and 20 control subjects who underwent psychopathologic examination using the SCL-90 questionnaire in Yasmin Kencana RSCM. The measurement of NPY levels was performed by ELISA method in Prodia Laboratory, Jakarta. All obtained data were kept in a magnetic plate, before the coding and editing process were performed. A validation process was then conducted to correct confounding variables and data analysis was carried out using SPSS 17. The comparison of NPY level was analyzed using unpaired t-test; while the relationship between NPY level and psychopathologic condition was analyzed by Pearson correlation test.

\section{RESULTS}

The samples included in this study were comprised of 20 subjects with PCOS and 20 subjects as controls. Among the sample group of PCOS patients, $90 \%$ had primary infertility and $10 \%$ had secondary infertility.

From 20 PCOS patients, we found that 6 subjects (30\%) had psychopathologic disorders detected through the SCL-90 questionnaire, with the aforementioned group scoring $>70$ points in the questionnaire. Data of these subjects were excluded in further analysis comparing the study group and the control group. Therefore, the number of subjects in the PCOS group was only 14 subjects in further analysis. 
Comparison of mean NPY levels in the study group and control group showed no significant difference of the mean blood NPY levels with a pvalue of $>0.05$.

Table 1. Comparison of NPY levels in non-obese PCOS patients without insulin resistance and normal women without insulin resistance

\begin{tabular}{llcccc}
\hline \hline & & N & Mean & $\begin{array}{c}\text { Standard } \\
\text { Deviation }\end{array}$ & $\begin{array}{c}\text { p- } \\
\text { value }^{*}\end{array}$ \\
\hline NPY levels & PCOS & 14 & 8.0271 & 3.92867 & 0.868 \\
& Control & 20 & 7.7840 & 4.31282 & \\
\hline \hline
\end{tabular}

${ }^{*} p$-value obtained using unpaired $t$-test

Table 2. Correlation of NPY levels with SCL-90 scores in PCOS group and control group

\begin{tabular}{|c|c|c|c|c|c|c|}
\hline & $\begin{array}{l}\text { Mean } \\
\text { NPY }\end{array}$ & SD & $\begin{array}{l}\text { Mean SCL- } \\
90 \text { Score }\end{array}$ & SD & $\begin{array}{l}\text { Corre- } \\
\text { lation }\end{array}$ & $\begin{array}{c}\text { p- } \\
\text { value }\end{array}$ \\
\hline $\begin{array}{l}\text { PCOS } \\
\text { group }\end{array}$ & 8.0271 & 3.928 & 31.79 & 19.56 & 0.225 & $0.439^{*}$ \\
\hline $\begin{array}{l}\text { Control } \\
\text { Group }\end{array}$ & 7.7840 & 4.312 & 14.35 & 14.354 & -0.012 & $0.960^{* *}$ \\
\hline
\end{tabular}

Table 3. The relationship of psychopathologic conditions and event of PCOS

\begin{tabular}{lccc}
\hline \hline & \multicolumn{2}{c}{ SCL-90 Category } & p-value* \\
\cline { 2 - 3 } & Normal & Psychopathology & \\
\hline PCOS group & 14 & 6 & 0.02 \\
Control group & 20 & 0 & \\
\hline \hline
\end{tabular}

*p-value obtained using Fisher's exact test

From the results of Fisher's exact test, a p-value $<0.05$ was obtained, and thus we can assume that there is a relationship between the event of PCOS and the presence of psychopathologic conditions.

\section{DISCUSSION}

In our study, we discovered that $30 \%$ of the total study group with PCOS had psychopathologic conditions that was not initially recognized by the patients and was detected using the SCL-90 questionnaire. A previous study by Elsenburch et al, which evaluated the presence of emotional psychopathologic conditions in PCOS patients using the same questionnaire, found that $15.4 \%$ of PCOS patients in their sample had psychological disor- ders. ${ }^{12}$ However, in the study by Elsenburch et al, the identified psychopathologic conditions were related to the increase in BMI. Meanwhile in this study, all of our samples had a BMI of $<25 \mathrm{~kg} / \mathrm{m}^{2}$. This is a new finding, where the occurrence of psychopathologic conditions in PCOS patients is not always related to an increase in BMI but could also occur in non-obese PCOS patients, and it might not be recognized by the patients themselves as well as their physician. The cause of psychopathologic conditions in these non-obese PCOS patients could not be determined as of now.

Baranowska et al conducted a study and found elevated NPY levels in both obese and non-obese PCOS patients. However, no significant relationship was found between NPY and changes in LH levels as a response to GnRH. Likewise, no significant relationship was found between NPY and insulin. Baranowska et al also found that the increment of NPY was not proportionately related to increment of BMI in non-obese PCOS patients. This study did not observe a significant relationship between NPY, insulin, and testosterone as well as the relationship between NPY levels and the percentage increment of LH as a response towards GnRH. ${ }^{7}$

In this study, we found that the mean NPY level in the sample group of non-obese PCOS patients was $8.02 \pm 3.92 \mathrm{pg} / \mathrm{ml}(95 \% \mathrm{CI} 2.39-18.66 \mathrm{pg} / \mathrm{ml}$ ), while the mean level for the control group was 7.78 $\pm 4.31 \mathrm{pg} / \mathrm{ml}(95 \%$ CI $0.74-15.47 \mathrm{pg} / \mathrm{ml})$. However, statistical analysis using unpaired t-test showed no significant difference between the two groups ( $\mathrm{p}>0.05)$. The samples and control group in this study had a HOMA score of $<2.5$, which became a cut-off point for the absence of insulin resistance. The results of this study were not similar to the findings of Baranowska et al since this study limits the subjects to those who did not have insulin resistance. In the study by Zaryevski et al, findings showed that elevated NPY in the hypothalamus would lead to hyperinsulinism and hypercorticism, as well as enhanced lipoprotein lipase activity and insulin resistance in muscles. ${ }^{13}$ This is consistent with findings by Genarelli et al who found no significant difference in the NPY levels of non-obese PCOS patients in comparison with non-obese normal subjects, ${ }^{8}$ as was found in our study. Findings by Genarelli et al showed that the lower levels of NPY in the obese PCOS group was associated with decreased sympathetic activity in the hypoglycemic state after insulin administration. ${ }^{8}$ 
From various literatures, it was known that the presence of decreased insulin sensitivity in PCOS patients is a secondary effect of disturbance in the homeostasis of positive energy and abdominal fat accumulation. ${ }^{14}$ Glucose homeostasis is maintained through a complex mechanism involving multiple factors and insulin. ${ }^{15}$ Several studies showed that PCOS patients experienced a period of subnormal glucose levels leading to increased caloric intake stimulation. Counter regulatory mechanisms will deal with this abnormal glucose state. However, in obese PCOS patients, this counter-regulatory response undergoes a disturbance and thus in these patients, episodes of hypoglycemia is not followed by increase in sympathetic activity and NPY levels as encountered in non-obese PCOS patients. Meanwhile, in non-obese PCOS patients, no significant difference in NPY levels was found compared to non-obese normal subjects. ${ }^{8}$ The comparable levels of NPY between the sample and control group was caused by the absence of insulin resistance in nonobese PCOS patients that comprise the sample group.

Therefore, it can be concluded that NPY levels are not correlated with the occurrence of increased GnRH pulsatility in non-obese PCOS patients without insulin resistance. However, further studies evaluating NPY levels in non-obese PCOS patients with insulin resistance is needed in order to understand the relationship between NPY levels and increased pulsatility in non-obese PCOS patients with insulin resistance.

In this study the trend of NPY levels was similar between the samples and control group, especially up to a cut-off point of $11 \mathrm{pg} / \mathrm{ml}$. However, when NPY levels exceed $11 \mathrm{pg} / \mathrm{ml}$, the trend moves towards the control group. The selection of controls has been aimed at minimizing influencing factors that may lead to increased NPY levels, such as presence of psychopathologic conditions, glucocorticoid consumption as well as use of narcotics and illicit drugs. Literatures state that consumption of sugar-rich food can increase secretion of NPY. ${ }^{16}$ Previous studies have also shown that there is an increment of leptin concentration of up to $50 \%$ during the late follicular and luteal phase, the mechanism of which is assumed to be due to increased leptin secretion by adipocytes as a response towards increased caloric intake or NPY secretion. ${ }^{17}$ In our study, during the time of blood collection, the stage of menstrual cycle was not taken into account. This may be the contributing factor leading to high NPY levels in several subjects in the control group.

As has been noted in previous studies, various factors influence the pulsatility of GnRH. One influential factor is pro-opiomelanocortin (POMC). Neurons producing POMC in the arcuate nucleus have synapses with cells producing GnRH. ${ }^{18}$ POMC is a peptide belong to the opioid class that has anorexigenic properties and inhibit GnRH secretion. It has also been stated that there is an overlapping intracellular signal pathway between leptin and insulin that brings to question whether these signals of leptin and insulin towards NPY and POMC plays a role in the regulation of GnRH secretion. However, further studies are needed on leptin, insulin, NPY and POMC, and their correlation that may affect GnRH pulsatility.

In this study, we found that the mean NPY level in a subgroup of non-obese PCOS patients without insulin resistance who experience psychopathologic conditions was $7.60 \pm 3.34 \mathrm{pg} / \mathrm{ml}(95 \%$ CI 3.37 11.83). Meanwhile, the mean NPY levels in the same group but who did not experience psychopathology was $8.02 \pm 3.92 \mathrm{pg} / \mathrm{ml}(95 \%$ CI 2.39 18.66). Statistical analysis found no significant difference between the two subgroups. Furthermore, Pearson correlation test in the control group found no correlation between SCL-90 scores and NPY levels, as was the fact in the PCOS group that were analyzed using Spearman correlation test. This was consistent with the study by Morgan et al, who found that in acute psychopathologic state, there was an increase in NPY levels that was positively correlated with cortisol and norepinephrine secretion. ${ }^{19}$ This elevation in NPY comprises a response mechanism towards a psychopathologic state, which could predict an individual's ability to adapt to the psychopathologic state. ${ }^{18}$ However, in chronic and uncontrolled psychopathologic conditions, a sympathetic dysregulation is present and causing a decline in NPY response towards psychopathologic conditions. ${ }^{20}$

From the findings in this study, we can assume that the psychopathologic state in non-obese PCOS patients without insulin resistance has no influence on NPY levels in the pathophysiology of PCOS. Psychopathologic condition is thought to have a direct effect on increased GnRH pulsatility, therefore leading to an increase in the LH:FSH ratio, a common event in PCOS. 


\section{CONCLUSION}

No significant difference found in the NPY levels of non-obese PCOS patients without insulin resistance in comparison with non-obese normal women. This study found that $30 \%$ of non-obese PCOS patients without insulin resistance experience a psychopathologic state, but this was found to have no influence on the NPY levels on non-obese PCOS patients without insulin resistance.

\section{REFERENCES}

1. Silfen ME, Denburg MR, Manibo AM, Lobo RA, Jaffe R, Ferin $M$. Early endocrine, metabolic, and sonographic characteristics of polycystic ovary syndrome (PCOS): comparison between nonobese and obese adolescents. J Clin Metab. 2003; 88: 4682-8

2. Blank S, McCartney C, Marshall J. The origins and sequelae of abnormal neuroendocrine function in polycystic ovary syndrome. Hum Reprod Update. 2006; 12(4): 351-61

3. Rajkhowa M, Glass M, Rutherford A, Michelmore K, Balen A. Polycystic ovary syndrome: a risk factor for cardiovascular disease. Brit J Obstet Gynaecol. 2000; 107: 11-8

4. Balen A. The patophysiology of polycystic ovary syndrome: trying to understand PCOS and its endocrinology. Best Prac and Res Clin Obstet Gynecol. 2004; 18(5): 685-706

5. Barontini M, Garcia M, Veldhuis J. Mechanism of hypothalamic-pituitary-gonadal disruption in polycystic ovary syndrome. Arch Med Res. 2001; 32: 544-52

6. Coiro V, Chiodera P, Melani A, Manfredi G, Jotti G, Casti A. Different plasma neuropeptide $Y$ concentrations in women athletes with and without menstrual cyclicity. Fertil Steril. 2006; 85(3): 767-9

7. Baranowska B, Radzikowska M, Dziubinska W, Kaplinski A, Roguski A, Plonowski A. Neuropeptide Y, leptin, galanin and insulin in women with polycystic ovary syndrome. Gynecol Endocrinol. 1999; 13(5): 344-51

8. Genarelli G, Holte J, Stridsberg M, Niklasson F, Bernez C, Backstrom T. The counter regulatory response to hypoglycemia in women with the polycystic ovary syndrome. Clin Endocrinol. 1997; 46: 167-74
9. Benson S, Hahn S, Tan S, Mann K, Janssen OE, Schedlowski $\mathrm{M}$. Prevalence and implications of anxiety in polycystic ovary syndrome: results of an internet-based survey in Germany. Hum Reprod. 2009; 24(6): 1446-51

10. Deeks A, Gibson-Helm E, Teede J. Anxiety and depression in polycystic ovary syndrome: a comprehensive investigation. Fertil Steril 2010; 93(7): 2421-3

11. Imani B, Marinus E, Egbert V. Predictors of patients remaining anovulatory during clomiphene citrate induction of ovulation in normogonadotropic oligomenorrheic infertility. J Clin Endocrinol Metab. 1998; 82(7): 2361-5

12. Elsenbruch S, Benson S, Hahn S, Tan S, Mann K, Pleger K. Determinants of emotional dipsikopatologiss in women with polycystic ovary syndrome. Hum Reprod. 2006; 21: 1092-9

13. Zaryevski N, Cusin I, Vettor R. Chronic intracerebroventricular neuropeptide $\mathrm{Y}$ administration to normal rats mimics hormonal and metabolic changes of obesity. Endocrinol. 1993; 133: 1753-8

14. Dunaif A, Xie J, Book C, Snecker B, Tang Z. Exessive insulin receptor serine phosphorylation in cultured fibroblast and in sceletal muscle. A potential mechanism for insulin resistance in the polycystic ovary syndrome. J Clin Invest. 1995; 96: $801-10$

15. Buller P, Rizza R. Regulation of carbohydrate metabolism and response to hypoglycemia. Endocrinol Metab Clinic of North America. 1989; 18: 1-25

16. Schneider J. Energy balance and reproduction. Physiology and Behavior 2004; 81: 289-317

17. Gabriel M, Jinagouda S, Sharma A, Boyadjian R, Saad M. Changes in plasma leptin during the menstrual cycle. Eur J Endocrinol. 1998; 139(5): 528-31

18. Hill J, Elmquist J, Elias C. Hypothalamic pathways linking energy balance and reproduction. Am J Physiol Endocrinol Metab. 2008; 294: 827-32

19. Morgan C, Wang S, Rasmusson A, Hazlett G, Anderson G, Charney D. Relationship among plasma cortisol, cathecolamin, neuropeptide $\mathrm{y}$, and human performance during exposure to uncontrollable psychopatologic. Psychosom Med. 2001; 63: 412-22

20. Morgan C, Rasmusson A, Wang S, Hoyt G, Hauger R, Hazlett G. Neuropeptide-Y, cortisol, and subjective dipsikopatologiss in humans exposed to acute psikopatologiss: replication and extension of previous report. Biol Psych 2002; 52: 13642 